\title{
Developing Yogyakarta's Halal Tourism Potential for Strengthening Islamic Economy in Indonesia
}

\section{FATKURROHMAN}

Gadjah Mada University, Yogyakarta, Indonesia.

fatkur@ugm.ac.id

\begin{abstract}
Yogyakarta is one of famed tourism cities in Indonesia. This city offers various cultures, natural uniqueness and culture heritage which is extremely valuable. Yogyakarta's uniqueness and beauty boosts domestic and foreign tourists come to this city to relish Yogyakarta's raciness. Foreign tourist from Malaysia gives high contribution in Yogyakarta tourism. In 2014, Malaysia tourist arrived to Yogyakarta approximately 25,280 which became the third largest foreign tourist after Netherlands and Japan. The aim of this research is to develop Yogyakarta's big potential as halal tourism destination for strengthening Islamic economy in Indonesia. The big potential of Yogyakarta as halal tourism destination can be seen from two aspects. Firstly, sum of big Malaysia tourist to Yogyakarta is chance to implement halal tourism. Secondly, in general, halal tourism will encourage Islamic economy growth in Indonesia. I use method of analysis of documents to do this research. The result of research is Yogyakarta has chance to be developed as one of halal tourism destinations in Indonesia. To sum up, Yogyakarta's big potential as halal tourism destination must be developed to actualize sustainable halal tourism in Yogyakarta.
\end{abstract}

Keywords: halal tourism; islamic economic; culture

\section{ABSTRAK}

Yogyakarta merupakan salah satu kota yang terkenal di Indonesia. Kota Yogyakarta menawarkan beragam keunikan alam dan warisan budaya yang sangat bernilai baik dari sisi sejarah maupun wisata. Keunikan dan beragam destinasi wisata yang beragam di Yogyakarta telah menjadi daya pikat bagi para wisatwan baik wisatawan domestik maupun wisatwan dari mancanegara. Wisatawan mancanegara khususnya dari Malaysia telah banyak memberikan kontribusi secara ekonomi terhadap pariwisata di Yogyakarta. Pada tahun 2014, Wisatawan dari Malaysia telah berkunjung ke Yogyakarta mencapai angka 25,280 wisatawan. 
Kunjungan wisatwan Malaysia menempati posisi ketiga terbesar setelah wisatawan dari Belanda dan wisatwan dari Jepang. Tujuan penelitian ini adalah untuk mengembangkan potensi besar wisata halal di Yogyakarta dalam memperkuat ekonomi Islam di Indonesia. Potensi besar kota Yogyakarta sebagai destinasi wisata halal dapat dilihat dari hal. Pertama, jumlah kunjungan wisatawan dari Malaysia merupakan sebuah potensi untuk mengembangkan konsep wisata halal secara serius di Yogyakarta. Kedua, secara umum, wisata halal memiliki kontribusi yang cukup signifikan dalam memperkuat ekonomi Islam di Indonesia. Penelitian ini menggunakan metode analisis dokumen. Hasil penelitian ini adalah Yogyakarta memiliki peluang yang besar untuk dikembangkan sebagai salah satu destinasi wsiata halal di Indonesia.

Kata Kunci: wisata halal; ekonomi islam; budaya

\section{INTRODUCTION}

Halal tourism is a hot topic in every conversation related to tourism in Indonesia. This cannot be separated from the position of Indonesia as a country that has the largest number of Muslims in the world. This largest number of Muslims has become a magnet for the tourism industry players to make the market share of the economy in growing the halal tourism industry in Indonesia. In short, halal tourism has nothing to do directly with the dominance of Islam in the tourism industry, but rather toward harnessing the economic potential in tourism development today. The trend of halal tourism in Indonesia from year to year has experienced significant growth in terms of quality and quantity related to the importance of the halal tourism industry. If viewed in terms of quality then the halal tourism industry of Indonesia has been proven by the improvement of quality both in terms of attractions, accommodation and access to tourist destinations. Meanwhile, in terms of quantity, the development of halal tourism in Indonesia showed a significant development with the acquisition of 12 nominations in the event World Halal Tourism Awards in 2016 in Dubai, United Arab Emirates. ' This fact indicates that the development of halal tourism in Indonesia is an economic potential that should be developed with the best that will give a good impact for economic growth of Indonesia.

The tourism sector has a large contribution in contributing economic growth figures in Indonesia, even the tourism industry is able to absorb the fourth largest workforce with the number reaching 10.18 million workers. ${ }^{2}$ The potential for the absorption of large manpower is certainly a great hope associated with the reduction of the number of poverty 
figures in Indonesia. As the number of poverty decreases, Indonesia's prosperity can be realized by the Indonesian government. Therefore, in order to spur economic growth in Indonesia, the Minister of Tourism, Arief Yahya, targets six things to spur the spirit of Indonesian tourism so that tourism can progress and grow rapidly. These are Firstly, tourism contribution to Gross Domestic Product (GDP) increased from 9 percent in 2014 to 15 percent in 2019. As of November 2015, tourism contribution to GDP is 9.5 percent. Second, foreign exchange increased from IDR 140 trillion in 2014 to IDR 280 trillion in 2019. Currently, tourism contribution to National GDP is estimated to reach 4 percent with foreign exchange of IDR 155 trillion. Third, the contribution to employment increased from 11 million in 2014 to 13 million by 2019. Fourth, the tourism competitiveness index increased from 70th rank in 2014 to 30 in 2019. Fifth, the number of foreign tourist arrivals (tourists) increased from 9.4 million in 2014 to 20 million by 2019. As of September 2015, the number of foreign tourists is 8.69 million. Sixth, the number of tourists travel nationwide increased from 250 million in 2014 to 275 million in 2019.

The six targets of the Ministry of Tourism will work well if taken seriously. For that, to realize it requires a strong effort so that from all circles can work with 3S. Three S is the smart, speed and solid of all parties for the six targets can be realized well achieve target number five and number six, namely the effort to boost foreign tourists and tourist tourism archipelago then the utilization of the potential of halal tourism to be one solution must be done well. The city of Yogyakarta as a tourist city, cultural city, city of education and city of struggle. The city of Yogyakarta is geographically located at 7 33'-8 12 'South Latitude and 110 00'-110 50' East Longitude, with an area of $23,185.80 \mathrm{~km}$. Administratively consists of 1 city and 4 districts, 78 sub-districts and 438 urban villages, namely Yogyakarta, Bantul, Kulon Progo, Gunung Kidul and Sleman. The city of Yogyakarta has an area of 32.50 square kilometers, has 14 districts and 45 villages. Bantul Regency has an area of 506.85 square kilometers, has 17 sub-districts and 75 villages. Kulon Progo Regency has an area of 586.27 square kilometers, has 12 districts and 88 villages. Gunung Kidul regency has an area of 1485.36 square kilometers, has 18 districts and 144 villages and Sleman district has an area of 574, 82 square kilometers, has 17 districts and 86 villages. Meanwhile, Yogyakarta in the South is bordered by the Indonesian Ocean, while in the East is bordered by Klaten, 
the south is bordered by Wonogiri, the west is bordered by Purworejo and North West bordering Magelang. ${ }^{3}$

The growth of global Islamic finance contributes to the emergence of world halal tourism. According to Ibrahim Wardi in his book entitled "Islamic Finance in the Global Economy" explains that Islamic finance can be understood from two things namely narrow perspective and large perspective. In the narrow perspective, Islamic finance is interest free banking, and in the large perspective, Islamic finance is financial operations conducted by Muslims. ${ }^{4}$ In General, Islamic finance institution is defined as are those that are based, in their objectives and operations, on Koranic principles. The rise of Islamic finance provides opportunities for the development of halal tourism, especially the development of halal tourism in Yogyakarta.

The number of Yogyakarta's Muslim population is $91.4 \%$ of 3,594,290 population total. ${ }^{5}$ This makes Yogyakarta very potential to become a halal tourism market. Halal tourism is not monolithic speaking alcohol and nonalcohol, but halal tourism is business. Even in European countries, many halal and halal restaurants are hygienic, safe and friendly. The city of Yogyakarta is one of 10 provinces designed by the Ministry of Tourism as a province that has the potential to develop halal tourism. The ten provinces are Aceh, West Sumatra, NTB (Lombok), DKI Jakarta, West Java, Riau Islands, Central Java, Yogyakarta, East Java and South Sulawesi. ${ }^{6}$ Yogyakarta has the potential for the development of halal tourism because Yogyakarta which inherits the Islamic Mataram kingdom has a culture attached to Islam, but also natural and artificial tourism also has the potential to be developed as a halal tourist destination. Visits of foreign tourists to Indonesia, especially Malaysia occupy the third largest tourist visit to Indonesia after the Netherlands and Japan. The fourth, fifth, sixth, seventh and eighth visits are France, Australia, Germany, China and Korea. While the slightest obstacle to the development of halal tourism in Yogyakarta is at the level of accommodation, the number of star hotels in Yogyakarta per 2015 is about 64 hotels with the following details of 5 star hotels with 7 hotels with 1518 rooms, 4 star hotels as many as 16 hotels with 1178 rooms, 3 star hotel as many as 19 hotels with number of 1737 rooms, 2 star hotels as many as 13 hotels with number of 648 rooms and 1 star hotel as many as 9 hotels with 397 rooms. While the number of non-star hotels in Yogyakarta in 2015 is 561 hotels with num- 
ber of rooms as many as 10,963, not including cottage tourism. ${ }^{7} \mathrm{He}$ is among 625 hotels in Yogyakarta, but there is only one hotel that is certified halal from the Majelis Ulama Indonesia (MUI), namely Hotel Cakra Kusuma located on Jalan Kaliurang. Halal certification at Hotel Cakra Kusuma involves the presentation of food and religious facilities. ${ }^{8}$ Another challenge related to the development of halal tourism in Yogyakarta is the lack of an Islamic Business Certification Institute (LSU) conductor.

The purpose of this study is to develop Yogyakarta's potential as halal tourism destination to encourage Islamic economy in Indonesia. This research method using qualitative method. In the view of Gary King, Robert D. Keohane and Sidney Verba, qualitative research is a study that uses one or more case studies using in-depth interviews or depth analysis of historical materials against a number of comprehensive events. For sampling technique, researcher uses deliberate sampling technique. This technique is used because it is able to obtain complete data with diverse data forms. According to C.R. Kothari ${ }^{9}$, states that deliberate sampling are a special unit that represents a large unit. The data collection of this research is using documentation technique. This technique considers some of the diversity of documents including letters, memoranda, official announcements, agendas, meeting conclusions and written reports. In addition, administrative documents, progress reports and other internal documents.

There are several books, journals and research discussing related to tourism and terrorism. Firstly, Battour's writing related the challenges and future of halal tourism describes Halal tourism is not an easy task because of the variance between the demands of non-Muslim tourists and Muslim tourists. ${ }^{10}$ Secondly, Samori et.al in his writing entitled Current trends on Halal tourism: Cases on selected Asian countries explains comparison between Malaysia and Japan. ${ }^{11}$

\section{FINDING AND DISCUSSION}

Currently, halal tourism is a prima donna in every seminar or discussion related to Indonesian tourism. Halal tourism began to grow rapidly in line with the growth of world Islamic economy. The dynamic growth of the economy at the international level has contributed to the development of halal tourism not only in the predominantly Muslim country, but also the few Muslim countries. Islamic minority countries that implement halal tourism for example are Singapore, Thailand, Philippines, Brazil, China, 
Taiwan, Vietnam, Japan, South Korea and even Russia. Then countries that have great attention to halal tourism are Indonesia, Malaysia, Turkey and countries in the Middle East. Term of halal cannot be separated from the five Islamic laws that exist in Islamic sharia such as obliged, haram, makruh, mubah and sunnah. According to Yusuf Al-Qaradawi is Halal is that which is permitted, with respect to which the law-giver, Allah, is allowed. ${ }^{12}$ Another definition, Halal can be defined as permissible or lawful in Islam. In reference to food, it is the Islamic dietary standard, as prescribed in the Shari'ah (Islamic Law). ${ }^{13}$ While Islamic tourism is "as tourism in accordance with Islam, those who are interested in keeping with their personal religious habits whilst traveling. Zamani-Farahani and Henderson explain that tourism in Islam is permitted as long as stipulations about conduct, dress, food and prayer are done well. ${ }^{14}$

The word "halal" is not a strange thing in the Islamic world. The word tourism has been mentioned both in al-Quran and hadith. Some arguments from al-Quran and Hadith the author of the quotation of the writings of Samori et.al in his writing entitled current trends on Halal tourism: Cases on selected Asian countries. Allah SWT says: "Do they not travel through the land, so that their hearts (and minds) may thus learn wisdom and their ears may thus learn to hear? Truly it is not their eyes that are blind, but their hearts which are in their breasts." (Surah al-Hajj: 46). In the another verse, He who forsakes his home in the cause of Allah, finds in the earth Many a refuge, wide and spacious: Should he die as a refugee from home for Allah and His Messenger, His reward becomes due and sure with Allah: And Allah is Oft-forgiving, Most Merciful." (Surah alNisa': 100). Meanwhile, Allah SWT put his words: "Travel through the earth and see how Allah did originate creation; so will Allah produce a later creation: for Allah has power over all things." (Surah al-Ankabut: 20). Another reference about halal tourism is in hadists. There are many hadiths such as that Ibrahim Abu Isma'il As-Saksaki narrated where Rasulullah, reported to have said: I heard Abu Burda who accompanied Yazid bin Abi Kabsha on a journey. Yazid used to observe fasting on journeys. Abu Burda said to him, "I heard Abu Musa several times saying that Allah's Apostle said, when a slave falls ill or travels, then he will get reward similar to that he gets for good deeds practiced at home when in good health." (Sahih al-Bukhari: Vol. 4, Book 52, Hadith 239). Then in another hadist, described that this has been recorded where it was nar- 
rated by Abu Said, Rasulullah says: "some of the companion of Rasulullah went on a journey till they reached some of the Arab tribes (at night). They asked the latter to treat them as guests, but they were refused. The chief was then bitten by a snake. When asked for help to cure the bite, the traveler refused, saying that since they were earlier on denied of hospitality, the travelers would only recite the Ruqyu for some payment." (Sahih al-Bukhari: Vol. 7, Book 71, Hadith 632). In another Hadith narrated by Ibn 'Abbas: (as regards the Verse): "You shall surely travel from stage to stage (in this life and in the Hereafter). (It means) from one state to another. That concerns your Prophet." Sahih al-Bukhari: Vol. 6, Book 60, Hadith $4 .{ }^{15}$

If we explore more deeply that the emergence of halal tourism or Islamic tourism is the development of Islamic travel and sharia tourism developed from religious tourism. Religious tourism means tourist wandering, with the religious element as one of its leading objectives. ${ }^{16}$ This means that the foundation halal tourism is from religious tourism which later developed into a sharia tour. Religious tourism appears to the surface because this tour departs from religious factors and religious tourism is the oldest form of tourism. Religious tourism emerges from the rapid development of global Islamic economy in recent decades. The relationship between religious tourism development process, sharia tourism and halal tourism can be described as the picture below. ${ }^{17}$

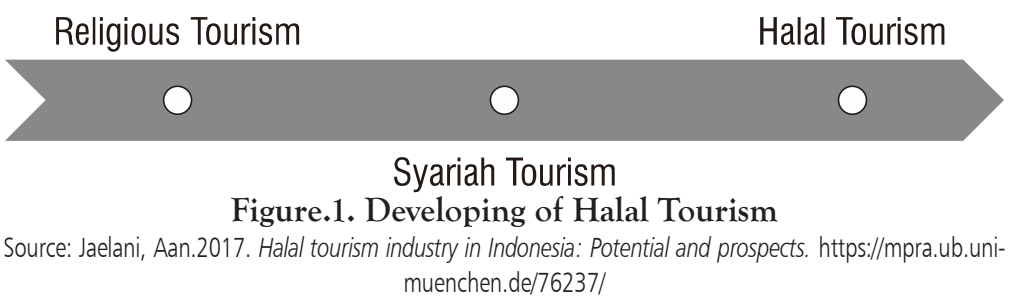

In the context of halal tourism, there are some terms that have the same substance with halal tourism, such terms are Islamic tourism, sharia tourism, halal travel, halal friendly tourism destination, Muslim-friendly travel destination and halal lifestyle. In relation to religious tourism, religious tourism is often associated with travel activities with religious intentions performed by religious communities of Islam, Christianity, Hinduism and Buddhism, usually by visiting holy places and religious figures (pil- 
grimages). Sharia tourism has a broader meaning of religious tourism. Sharia tourism has seven main criteria that must be known well. (3) Sharia tourism avoids idolatry and khurafat (4) Sharia free tourism (5) Sharia tourism maintains security and convenience (6) Sharia tourism must preserve the environment (7) Sharia tourism must respect the values of social culture and local wisdom. ${ }^{18}$

According to Heri Sucipto and Fitria Andayani, there are several characteristic syariah tour: ${ }^{19}$

1. Sharia tourism destination

a. Destinations include nature, cultural and artificial tours

b. Good and holy worship facilities are available

c. Halal food and beverage are available

d. Art and cultural performances and attractions that are not in conflict with the general criteria of sharia tourism

e. Cleaned sanitation and environment

2. Accommodation

a. Available decent and sacred facilities

b. There are facilities that make it easy for worship

c. Halal food and beverages are available

d. The facilities and atmosphere are safe, comfortable and conducive to family and business

e. Clean and sanitary environment

3. Sharia Travel Bureau

a. Organize travel or tour packages that fit the general criteria of sharia tourism

b. Have a list of accommodation that complies with the general guidelines of syariah tourism accommodation

c. Have a list of food and beverage business that is in accordance with the guide of food provider and minister of sharia tourism

4. Criteria of guide Syariah

a. Understand and be able to implement syariah values in performing their duties

b. Good, communicative, friendly and honest and responsible Habit

c. Be courteous and attractive in accordance with Islamic values and ethics

d. Have work competence according to applicable profession standard 
5. Sharia Flight

a. Provides flights to a number of Islamic countries

b. Providing halal food during the trip

c. Providing maximum service and friendly in accordance with Islamic principles

d. The stewardesses were well-dressed

6. Shopping Center and Stopover Place
a. Providing a decent mosque / mosque
b. The location of the mosque is not in a hidden place
c. Keep the building clean.

Table.1. Differences among Conventional, Religious and Syariah or Halal Tourism

\begin{tabular}{llll}
\hline ASPECT & $\begin{array}{l}\text { CONVENTIONAL } \\
\text { TOURISM }\end{array}$ & RELIGIOUS TOURISM & $\begin{array}{l}\text { SYARIAH/HALAL } \\
\text { TOURISM }\end{array}$ \\
\hline Object & $\begin{array}{l}\text { Nature, culture, heritage } \\
\text { and cuisine }\end{array}$ & $\begin{array}{l}\text { Worship place and historical } \\
\text { place }\end{array}$ & All \\
\hline Aim & Entertaining & Increasing spirituality & Increasing spirituality \\
& & & entertainingly \\
\hline Target & Entertaining only & Spiritual aspect & Religious awareness \\
\hline Guide & Guide's expertise in & Understanding figure and place & Syariah role in daily life \\
& explaining tourist & & \\
\hline Worship & Complementary & Complementary & Worship as part of \\
facility & & & entertaining package
\end{tabular}

\begin{tabular}{llll}
\hline Culinary & General & General & Halal \\
\hline $\begin{array}{l}\text { Community } \\
\text { and }\end{array}$ & Complementary & Complementary & Integrated in syariah \\
environment & & & \\
relations & & & \\
\hline Itinerary & Whenever & Certain time & Keep prayer time
\end{tabular}


Indicators related to sharia tourism will be a good guide not only for tourists but also actors of tourism. To carry out these indicators are expected to contribute well to the realization of Islamic tourism in Indonesia. A very clear guide related to sharia tourism will provide many conveniences for the realization of Islamic tourism in the future. When the actors of sharia tourism have to know and understand related to the indicators of sharia tourism then the actors of sharia tourism will be easy to implement it. This will certainly develop syariah tourism not only in the city of Jakarta, but also other cities that have the potential for developing Islamic tourism. To realize related to the development of Islamic tourism should get support from five main components called pentahelix namely scholars, businesspeople, community, government, and media. ${ }^{20}$

The word shariah has been used in the banking industry since 1992, which then shifted to the insurance shariah, sharia pawnshops, sharia hotels and sharia tourism. If we explore further, Islamic tours of the type of pilgrimage tours and religious tourism. In 1967, the UNWTO (United Nations World Tourism Organization) organized a Conference in Cordoba aimed at bridging the dialogue space of culture, religion and civilization. Associated with the dynamics in conventional tourism, religious tourism and sharia tourism or halal tourism. Here the authors show the differences that exist in conventional tours, tours and sharia tours or Halal tours.

Based on the differences associated with conventional tourism, religious tourism and halal or sharia tours, then we can be clearer in distinguishing the three forms of tourism. Identifying halal tourism to conventional tourism we can recognize from the tour package. The special feature of halal tour packages is that the tour package which includes the destination of Islam-friendly tourists, hotels, restaurants and halal spas. Halal is a food product that has the properties of cleanliness, safety and quality. In developing halal tourism or sharia tourism there are seven sectors that must be considered for halal tourism can really grow rapidly in the future. The seven sectors are culinary, Islamic finance, insurance industry, fashion, cosmetics, pharmacy and tourism. If this is developed seriously then the development of Indonesian halal tourism will be developed and become a reference for the countries of the international world.

The potential of halal tourism in Indonesia is very large giving hope that halal tourism will contribute to economic growth in Indonesia. This should be done by Indonesia because Indonesia has a lot of potential 
related to the development of halal tourism. One of them is the understanding related to Islam in Indonesian society is good enough, that is to live give a broader understanding about the world of halal tourism industry. If we talk related to the halal tourism industry, then the trendsetter of world halal tourism is Malaysia, Turkey, Brunei Darussalam and Middle East. Therefore, Indonesia's position is very strategic to be able to compete with countries outside Indonesia. This has been proven by the victory of Indonesia in the arena of World Halal Tourism Awards 2016 di Abu Dhabi, Uni Emirat Arab. Indonesia won 12 nominations from 16 nominations, these are the 12 winners of the World Halal Tourism Awards 2016:21

1. World's Best Airline for Halal Travellers - Garuda Indonesia.

2. World's Best Airport for Halal Travellers - Sultan Iskandar Muda International Airport, Aceh Indonesia.

3. World's Best Family Friendly Hotel - The Rhadana Hotel, Kuta, Bali, Indonesia.

4. World's Most Luxurious Family Friendly Hotel - Trans Luxury Hotel Bandung Indonesia.

5. World's Best Halal Beach Resort - Novotel Lombok Resort \& Villas, Lombok, NTB.

6. World's Best Halal Tour Operator - Ero Tour, West Sumatera Indonesia

7. World's Best Halal Tourism Website www.wonderfullomboksumbawa.com, Indonesia.

8. World's Best Halal Honeymoon Destination - Sembalun Village Region, Lombok, Nusa Tenggara Barat, Indonesia

9. World's Best Hajj \& Umrah Operator - ESQ Tours \& Travel, Jakarta, Indonesia.

10.World's Best Halal Destination - West Sumatera, Indonesia.

11.World's Best Halal Culinary Destination - West Sumatera, Indonesia

12.World's Best Halal Cultural Destination - Aceh Indonesia.

While in 2015, in the event WHAT, Indonesia Indonesia managed to occupy five nominations namely World best family friendly hotel, World best cultural destination, World's best culinary destination, World's best halal honeymoon destination, and World's best halal tourism destination. ${ }^{22}$ 


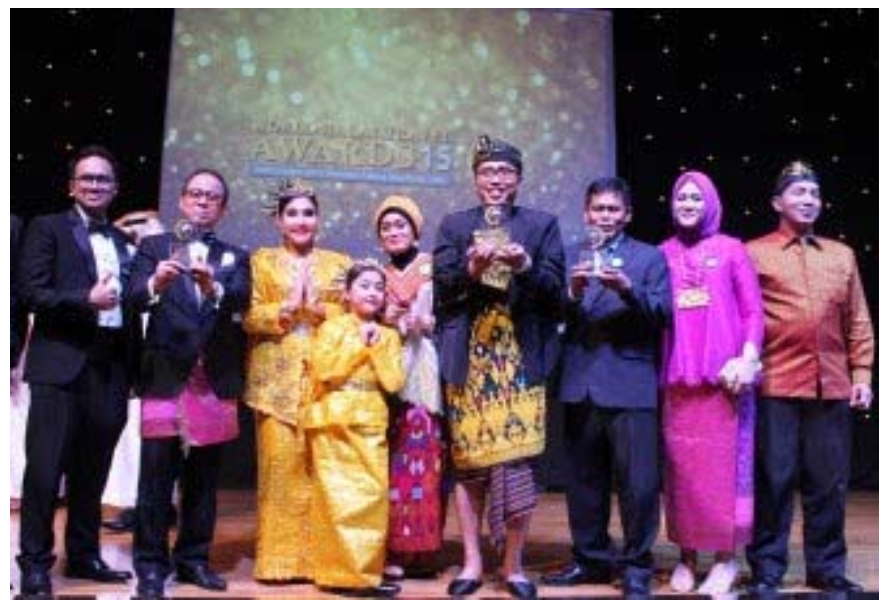

Figure 2: Indonesia Wins World Halal Travel Awards 2015 Source: http://www.islamiceconomic.org/indonesia-wins-world-halal-travel-awards-2015.html

Indonesia's victory at the WHAT event in 2015 and 2016 proves that Indonesia has considerable potential to shift countries such as Malaysia, Turkey, Brunei Darussalam and Middle Eastern countries in terms of world halal tourism. This potential must be maintained and properly maintained so that Indonesian halal tourism can contribute to the development of Indonesia in the future.

Yogyakarta is one of the provinces set by the Ministry of Tourism as one of halal tourism destinations along with 9 other regions in Indonesia. The nine areas are Lombok, Jakarta, Batam, Aceh, West Java, West Sumatra, East Java, Central Java and South Sulawesi. ${ }^{23}$ The position of Yogyakarta as one of the halal tourism destinations is the right thing because the first two main things are the number of tourist visits from Malaysia visiting Yogyakarta and the second reason is the presence of domestic tourists more comfortable with halal tourism. The number of Malaysian tourists ranked third largest after the Netherlands and Japan. This shows that the potential for increasing Malaysian tourists to come to Yogyakarta becomes the homework of the Yogyakarta government. The number of Malaysian tourists coming to Yogyakarta in 2013, 2014 and 2015 are 22,277, 25,280 and 27,000 tourists. To increase the number of Malaysian tourist to visit Yogyakarta, Yogyakarta government should clean up related to the supporting facilities of sharia tourism be it accommodation sector, attractions, accessibility and ancillary tours. Tourism destinations both based on 
nature, culture and artificial must be optimized by the government of Yogyakarta. While at the level of domestic tourists, with the number of Muslims who reach the majority in Indonesia, halal tourism becomes a necessity. This means that if in 2015, the national archipelago that came to Yogyakarta 3.4 million then with the many halal destinations in Yogyakarta, it will be a tower of the domestic tourists to vacation to Yogyakarta.

Table 2. Domestic and foreign tourist visiting in Yogyakarta 2011-2015

\begin{tabular}{lllllll}
\hline YEAR & $\begin{array}{l}\text { FOREIGN } \\
\text { TOURIST }\end{array}$ & $\begin{array}{l}\text { GROWTH } \\
(\%)\end{array}$ & $\begin{array}{l}\text { DOMESTIC } \\
\text { TOURIST }\end{array}$ & $\begin{array}{l}\text { GROWTH } \\
(\%)\end{array}$ & $\begin{array}{l}\text { FOREIGN AND } \\
\text { DOMESTIC } \\
\text { TOURISTS }\end{array}$ & $\begin{array}{l}\text { GROWTH } \\
(\%)\end{array}$ \\
\hline 2011 & 169,565 & 9.57 & $1,438,129$ & 1.37 & $1,607,694$ & 2.17 \\
\hline 2012 & 197,751 & 16.62 & $2,162,422$ & 50.36 & $2,360,173$ & 46.80 \\
\hline 2013 & 235,893 & 19.29 & $2,602,074$ & 20.33 & $2,837,967$ & 20.24 \\
\hline 2014 & 254,213 & 7.77 & $3,091,967$ & 18.83 & $3,346,180$ & 17.91 \\
\hline 2015 & 308,485 & 21.35 & $3,813,720$ & 23.34 & $4,122,205$ & 23.19 \\
\hline 2016 & 355,313 & 15.18 & $4,194,261$ & 9.98 & $4,549,574$ & 10.37 \\
\hline
\end{tabular}

Source: Tourism statistic of Yogyakarta, 2015 and Tourism statistic of Yogyakarta, 2016.

Table 3. Top Three Foreign Tourist Visiting in Yogyakarta

\begin{tabular}{lllll}
\hline TOURISTS & 2013 & 2014 & 2015 & 2016 \\
\hline Netherlands & $11 \%$ & $11 \%$ & $11 \%$ & $13 \%$ \\
\hline Japanese & $10 \%$ & $10 \%$ & $10 \%$ & $7 \%$ \\
\hline Malaysian & $10 \%$ & $10 \%$ & $9 \%$ & $10 \%$ \\
\hline
\end{tabular}

Source: Tourism statistic of Yogyakarta, 2016.

Based on the above data, we can conclude that the range of 2011 to 2016, the data of foreign tourist visits to Yogyakarta has increased significantly from the number of visits 169,565 to 355.313 in 2016 . While domestic tourist arrivals in 2011 amounted to 1.438 .129 increased to $4,194,261$ on year 2016 . The number of foreign tourists visiting Yogyakarta is dominated by the Netherlands, Japan and Malaysia. The number of Malaysian tourists who are relatively stable at $10 \%$ rate during the year 2013-2016 is a great potential in the development of halal tourism in Yogyakarta. This of course also affects the increasing Islamic economic activity in Yogyakarta.

\section{CONCLUSION}

Halal tourism is a kind of tourism that is currently becoming an inter- 
esting thing to be developed by the government of Indonesia. Yogyakarta as one of the areas appointed by the Ministry of Tourism as a destitution of halal tourism in general is ready to organize halal tourism. Yogyakarta has a lot of potential for both nature-based tourism, culture and artificial to be developed into a halal tourism. Implementation of halal tourism will provide a significant economic impact for the people of Yogyakarta because tourists both foreign and national tourists will visit Yogyakarta. Foreign tourists, especially tourists from Malaysia and domestic tourists will be pampered with halal tourist destinations. To prepare halal tourism destinations, the government of Yogyakarta should also be able to guard halal tours can be comfortable for everyone. In addition, the government of Yogyakarta should also provide education to the public that halal tourism is not a certain religious autonomy, but halal tourism purely because of business interests.

\section{ENDNOTES}

1 http://www.thejakartapost.com/travel/2016/10/12/12-indonesian-entitiesvie-for-world-halal-tourism-award.html

2 Kurniawan Gilang Widagdyo, "Analisis Pasar Pariwisata Halal Indonesia" in The Journal of Tauhidinomics Vol. 1 No. 1 (2015), p. 73

3 Dinas Priwisata Daerah Istimewa Yogyakarta, Statistik Kepariwisataan 2015 (Yogyakarta: tidak diketahui penerbit, 2016), p.iii

4 Ibrahim Warde, Islamic Finance in the Global Economy (Edinburg: Edinburgh University Press, 2000), p. 20.

5 https://en.wikipedia.org/wiki/Special_Region_of_Yogyakarta

6 http://www.antaranews.com/en/news/104074/indonesia-developing-halaltourism

7 Dinas Priwisata Daerah Istimewa Yogyakarta, Statistik Kepariwisataan 2015 (Yogyakarta: tidak diketahui penerbit, 2016), pp.xvii-xviii

8 http://rumahtin.com/jogja-destinasi-wisata-halal/.

9 C.R. Kothari, Research Methodology: Methods and Techniques (New Delhi: New Age International Publisher, 2004), p.3

10 Mohamed Battour and Mohd Nazari Ismail, "Halal tourism: Concepts, practises, challenges and future" in Tourism Management Perspectives 19 (2016),pp 150-154.

11 Zakiah Samori, Nor Zafir Md Salleh and Mohammad Mahyuddin Khalid, "Current trends on Halal tourism: Cases on selected Asian countries" in Tourism Management Perspectives 19 (2016) pp 131-136.

12 Sheikh Yusuf al-Qaradawi, The Lawful and the prohibited in Islam (Cairo:AlFalah Foundation For Translation, Publication\&Distribution, 2001), p. xxv

$13 \mathrm{Http}: / /$ www.halalhmc.org/DefintionOfHalal.htm 
14 Hamira Zamani-Farahani and Joan C. Henderson, "Islamic Tourism and Managing Tourism Development in Islamic Societies: The Cases of Iran and Saudi Arabia”, in International Journal Of Tourism Research, 12, (2010), pp. 79. 89.

15 Zakiah Samori, Nor Zafir Md Salleh and Mohammad Mahyuddin Khalid, "Current trends on Halal tourism: Cases on selected Asian countries", in Tourism Management Perspectives 19 (2016), pp. 131-136

16 Maciej Ostrowski, Pilgrimages or Religious Tourism (2010), p.53.

17 Aan Jaelani, "Halal tourism industry in Indonesia: Potential and prospects", in Munich Personal RePEc Archive (2017) pp 9-12.

18 Aan Jaelani, "Halal tourism industry in Indonesia: Potential and prospects", in Munich Personal RePEc Archive (2017) p. 8.

19 Ade Ela Pratiwi, "Analisis Pasar Wisata Syariah di Kota Yogyakarta" in Jurnal Media Wisata, Vol 14, No.1 (2016), p.350.

20 http://www.thejakartapost.com/travel/2017/09/15/airasia-unveils-indonesiainspired-aircraft-livery-design.html?fb_comment_id=154096170263. 3666_1541851279211375

21 http://www.indonesia.travel/en/post/indonesia-dominates-world-halal-tourism-awards-2016-winning-12-top-categories.

22 https://lifestyle.sindonews.com/read/1056127/156/lombok-berhasilmenangkan-world-halal-travel-awards-2015-1445815728.

23 http://www.cheria-travel.com/2017/05/10-wilayah-indonesia-yangmenjadi.html.

\section{BIBLIOGRAPHY}

Battour, Mohamed and Ismail,Nazari, Mohd. 2016. "Halal tourism: Concepts, practises, challenges and future” in Tourism Management Perspectives 19, pp 150-154

Dinas Priwisata Daerah Istimewa Yogyakarta, Statistik Kepariwisataan 2015 (Yogyakarta: tidak diketahui penerbit, 2016).

(Yogyakarta: tidak diketahui penerbit, 2017).

Farahani, Zamani, Hamira and Henderson,C, Joan. 2010 "Islamic Tourism and Managing Tourism Development in Islamic Societies: The Cases of Iran and Saudi Arabia”, in International Journal of Tourism Research, 12, pp. 79-89.

Jaelani, Aan. 2017. "Halal tourism industry in Indonesia: Potential and prospects", in Munich Personal RePEc Archive, pp 9-12.

Kothari. C.R, 2004. Research Methodology: Methods and Techniques. New Delhi: New Age International Publisher.

Ostrowski, Maciej. 2010. "Pilgrimages or Religious Tourism", in peregrinus cracoviensis. pp. 53-61

Pratiwi, Ela, Ade. 2016. "Analisis Pasar Wisata Syariah di Kota Yogyakarta" in Jurnal Media Wisata, Vol 14. No.1, p.345-364.

Samori, Zakiah, Salleh, Md, Zafir, Nor and Khalid, Mahyudian, Mohammad. 
2016, "Current trends on Halal tourism: Cases on selected Asian countries", in Tourism Management Perspectives 19, pp. 131-136

Warde,Ibrahim. 2000. Islamic Finance in the Global Economy. Edinburgh: Edinburgh University Press.

Widagdyo, Gilang, Kurniawan. 2015."Analisis Pasar Pariwisata Halal Indonesia" in The Journal of Tauhidinomics Vol. 1 No. 1, p. 73-80

Zakiah Samori, Nor Zafir Md Salleh and Mohammad Mahyuddin Khalid. 2016, "Current trends on Halal tourism: Cases on selected Asian countries" in Tourism Management Perspectives 19, pp. 131-136.

\section{Internet Access}

http://www.thejakartapost.com/travel/2016/10/12/12-indonesian-entities-viefor-world-halal-tourism-award.html

https://en.wikipedia.org/wiki/Special_Region_of_Yogyakarta

http://www.antaranews.com/en/news/104074/indonesia-developing-halal-tourism

http://www.thejakartapost.com/travel/2017/09/15/airasia-unveils-indonesiainspired-aircraft-livery-design.html?fb_comment_id=1540961702633666_ 1541851279211375

http://www.indonesia.travel/en/post/indonesia-dominates-world-halal-tourismawards-2016-winning-12-top-categories.

https://lifestyle.sindonews.com/read/1056127/156/lombok-berhasil-menangkanworld-halal-travel-awards-2015-1445815728.

http://rumahtin.com/jogja-destinasi-wisata-halal/.

http://www.cheria-travel.com/2017/05/10-wilayah-indonesia-yang-menjadi.html. Http://www.halalhmc.org/DefintionOfHalal.htm 